\title{
THE CONTROLLED INDUCTION OF PUBERTY
}

\author{
A.M. PATERSON \\ A.R.C. Group for Hormones and Reproduction in Farm Animals, \\ University of Nottingham School of Agriculture, Sutton Bonington, \\ Loughborough, Leicestershire, UK
}

Puberty, defined as the time at which ovulation and oestrus first occur in association with normal luteal function, usually takes place at about 200 days of age in the gilt (Duncan and Lodge, 1960). As the replacement gilt is reared solely for reproductive purposes, a delay in the attainment of puberty means a delay in the commencement of productive life. With the recent trend towards intensive confinement systems of pig production it has become increasingly desirable to be able to control the onset of puberty in the gilt. As discussed in Chapter 6, age at puberty can be affected by many factors including nutrition, genotype and the environment. Although there are numerous reports in the literature concerning environmental or physiological conditions which may either hasten or retard puberty in the gilt, few include studies of the associated hormonal changes. Therefore in reviewing those methods used in an attempt to control the onset of puberty in the gilt, particular emphasis is given to the endocrinology and mode of action of the technique involved.

\section{The endogenous control of puberty}

An understanding of the endogenous control of puberty, which is central to attempts to control puberty, has been hampered by a lack of basic research on this topic in the pig. As has been pointed out in Chapter 5, it is still not possible to explain fully the pubertal process in the pig in terms of the neuroendocrine mechanisms involved. However, some important points are clear and bear consideration at this stage.

The hypothalamic-pituitary unit is essentially intact at birth. The hypothalamus contains gonadotrophin releasing hormones and the pituitary is capable of releasing gonadotrophins in response to synthetic releasing hormones (Debeljuk, Arimura and Schally, 1972; Foster, Cook and Nalbandov, 1972). Recent work in the sheep (Ryan and Foster, 1980) has shown that as puberty is approached the frequency of episodic luteinizing hormone (LH) release increases to about one episode per hour. This is believed to provide the trophic stimulus for final follicular development, which in turn increases oestradiol production and leads to the induction of the first pre-ovulatory LH surge as the positive feedback mechanism becomes operative. These workers were successful in inducing 
precocious puberty in ewe lambs by mimicking the increased LH pulse pattern with exogenous $\mathrm{LH}$. Such work has not been reported in the pig but the frequency of pulsatile LH release in the gilt does increase during development (see Chapter 5); the model for the initiation of puberty as proposed for the lamb may therefore also be applicable to the gilt.

The mechanisms governing the changes in gonadotrophin secretion during development have been recently reviewed (Levasseur, 1977; Foxcroft, 1978; Foster, 1980; Elsaesser, Chapter 5) and these mechanisms will not be considered in detail in this review. In general, two theories have evolved to explain the increase in gonadotrophin secretion as puberty is approached and conflict exists as to which theory best explains the onset of puberty, although they are certainly not mutually exclusive. The first involves the concept of differential feedback sensitivity (Ramirez and McCann, 1963; Grumbach et al., 1974) and has become known as the classic 'gonadostat' hypothesis. This postulates that the hypothalamus is highly sensitive to negative feedback by low levels of circulating oestrogens, which suppress the secretion of releasing hormones and hence the gonadotrophins. As puberty is approached there is a change in the set point of the hypothalamus which becomes less sensitive to negative feedback, allowing secretion of gonadotrophins to increase. The second theory proposes that there is specific inhibition of the secretion of releasing hormones from the hypothalamus by the central nervous system (Davidson, 1974; Levasseur, 1977). The cortex, limbic system and pineal gland are all believed to have some influence on the hypothalamus in a balanced inhibition of the secretion of releasing hormones (Gorski, 1974). These extra-hypothalamic structures presumably monitor factors in the internal and external environment and mediate their influence on gonadotrophin secretion via neuroanatomical pathways.

\section{Induction of puberty with the male}

The introduction of the mature male to the prepubertal female can advance and synchronize puberty in a number of species. This phenomenon was first described in the mouse by Whitten (1956a,b) and has since been reported in rats (Cooper and Haynes, 1967), deer-mice (Bronson and Marsden, 1964), sheep (Dýrmundsson and Lees, 1972) and pigs (du Mesnil du Buisson and Signoret, 1962; Brooks and Cole, 1969; 1970). The results obtained from using boars to induce puberty have been reviewed by Hughes (Chapter 6 ) and will not be repeated here.

In mice it is the odour of the male's urine which is the major exteroceptive factor involved in the stimulation of the fermale (Dominic, 1965; Bronson and Whitten, 1968). The physical presence of the male is not essential as females can be stimulated by transferring bedding soiled with male urine to their cage (Parkes and Bruce, 1962; Vandenbergh, $1969 ; 1975)$, but it must be changed frequently to ensure a response. Bronson and Maruniak (1975) found that while urine alone stimulated a uterine weight response, physical contact with an intact male or urine plus physical contact with a castrated male produced a much stronger response. They concluded that the main stimulatory effect was pheromonal but tactile cues were also important. 
Wilson and Bossert (1963) divided pheromones into two main typessignaller pheromones which produce a behavioural response and primer pheromones which cause a physiological change. In the pig the source of the pheromones which stimulate puberty is not well defined. When Kinsey et al. (1976) exposed gilts to a range of treatments including boar urine odour and physical contact with boars, they found that boar contact advanced puberty but the odour of their urine did not. Kirkwood and Hughes (1980) were able to advance puberty by exposing gilts to the odour of a vacant boar pen, but the administration of the urinary pheromone $5 \alpha$-androst-16-en-3-one $\left(\Delta^{16}\right)$ which has signaller pheromone properties (Reed, Melrose and Patterson, 1974) had no effect on the age of gilts at puberty. This suggests that the primer pheromones which stimulate puberty in the gilt are not of urinary origin. Boar saliva is known to contain a reproductively-active pheromone complex in which the major active compound is $3 \alpha$-androstenol (Gower, 1972; Booth, 1975; 1977). Having studied the urinary pheromones and the mating behaviour of pigs, Kirkwood, Forbes and Hughes (1981) have postulated that the source of the primer pheromone in the boar is the submaxillary salivary gland.

The physiological mechanism by which the male stimulates puberty in the female mouse has been studied by Bronson and his co-workers at Austin, Texas. Their work has established that the introduction of the male causes a rise in the basal $\mathrm{LH}$ concentrations of the female (Bronson and Desjardins, 1974; Bronson and Maruniak, 1976). This rise takes place within 30 minutes of the introduction of the male and the ovary responds to the higher concentration of LH by secreting oestradiol. Circulating levels of oestradiol are elevated in six to twelve hours and remain elevated for up to 48 hours leading to the initiation of positive feedback as LH, FSH and progesterone concentrations increase in a pattern which mimics that seen in the proestrus phase of the adult cyclic mouse and ovulation takes place.

It has been suggested that the period of elevated oestrogen is essential for the final maturation of the positive feedback system in the hypothalamus, which facilitates the release of gonadotrophins in response to oestrogen stimulation. In this context, Bronson (1975) and Bronson and Maruniak (1976) have postulated that the effect of the male is exclusively on basal levels of $\mathrm{LH}$ and oestrogen and that the secretion of the other hormones are altered indirectly by the action of oestradiol.

Few studies on the hormonal events associated with the onset of puberty in the gilt after exposure to boars have been published. Recent work at the University of Missouri (Paterson, Cantley and Day, 1980; Esbenshade et al., 1982) has characterized some of the changes taking place at this time but the picture is by no means yet complete. Blood samples were taken twice daily from nine gilts around the time of relocation and exposure to mature boars. Figure 7.1 shows the mean hormone levels in these gilts from day -6 to day 6 , with day 0 being the first day of the pubertal oestrus. Plasma oestradiol-17 $\beta\left(E_{2}\right)$ began increasing from day -5 and reached peak levels during proestrus, on day $-3(n=5)$ or day $-2(n=4)$. Plasma LH levels prior to day -1.5 and after day 1.5 fluctuated between 0.5 and $1 \mathrm{ng} / \mathrm{ml}$ and were considered basal. The pre-ovulatory surge of LH was measured on day $-1(n=4)$ or day $0(n=5)$. Progesterone concentrations were less than $0.3 \mathrm{ng} / \mathrm{ml}$ until after oestrus and then they rose to about 

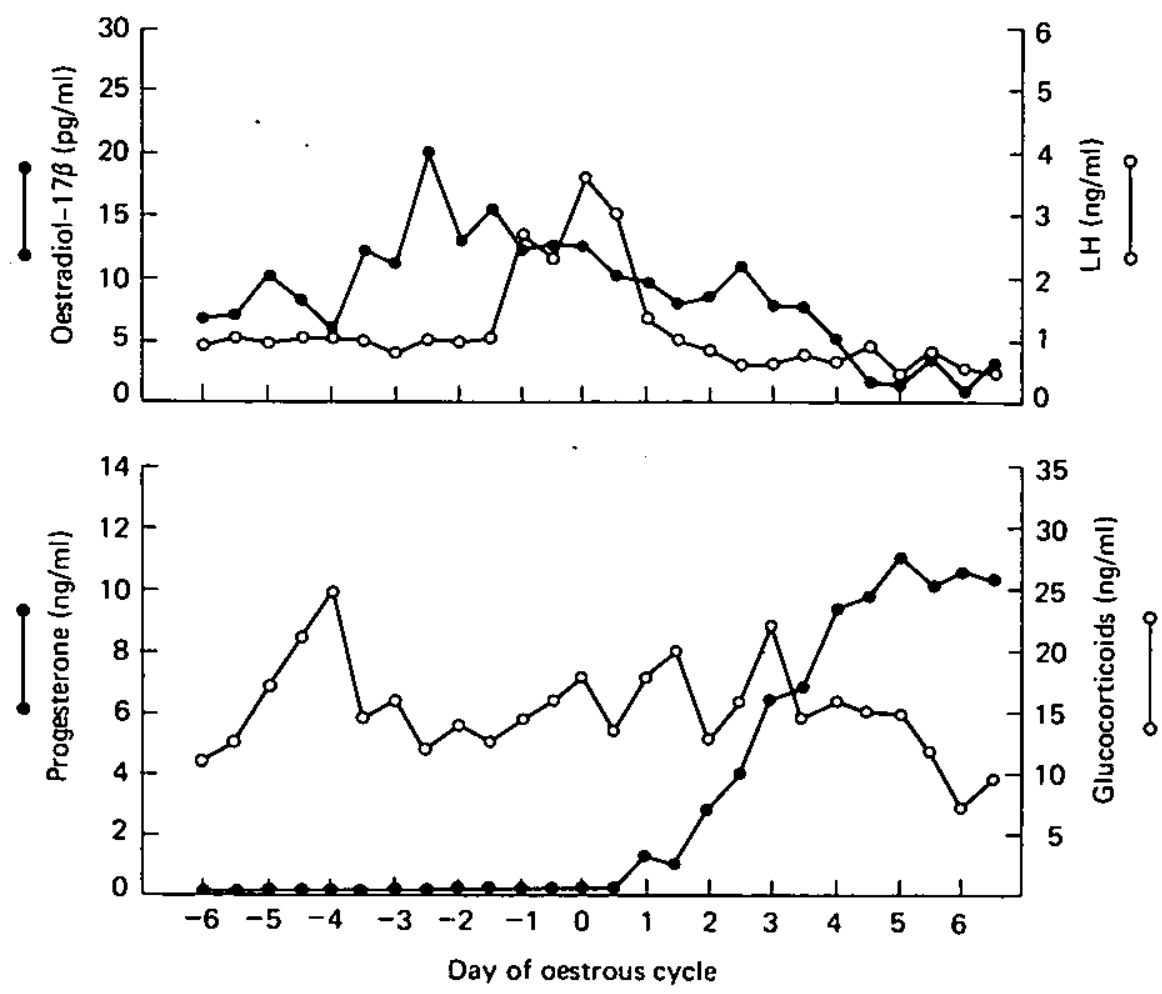

Figure 7.1 Mean plasma hormone concentrations at the onset of puberty in relocated gilts $(n=9)$. From Esbenshade et al. (1982)

$11 \mathrm{ng} / \mathrm{ml}$ by day 5 due to the formation of corpora lutea. Cortisol levels fluctuated widely, ranging from $7.4-24.5 \mathrm{ng} / \mathrm{ml}$ and they did not appear to be related to oestrus or ovulation.

In a second experiment blood was collected from four gilts every six hours from boar exposure until after puberty. The hormonal patterns were similar in each gilt, although they were out of phase with each other as the gilts reached puberty at different times after exposure to the boars. Figure 7.2 shows the mean LH and $E_{2}$ levels in these gilts arranged with respect to the onset of oestrus ( 0 hours). Plasma $E_{2}$ rose from basal levels and remained elevated for a mean time of 83 hours before the onset of oestrus. Peak levels were measured at -18 hours and $E_{2}$ had returned to basal levels by +12 hours. Plasma $\mathrm{LH}$ was basal throughout with the exception of the pre-ovulatory surge.

The hormonal pattern of oestradiol and $\mathrm{LH}$ observed during the follicular phase leading to first oestrus in these prepubertal gilts was similar to the pattern observed during the follicular phase of the oestrous cycle (Henricks, Guthrie and Handlin, 1972; Guthrie, Henricks and Handlin, 1972; Shearer et al., 1972) and during the follicular phase of gilts synchronized with a synthetic progestin (Redmer and Day, 1981). These data indicate that the increase in plasma oestrogen prior to first oestrus is due to the initiation of follicular growth. 


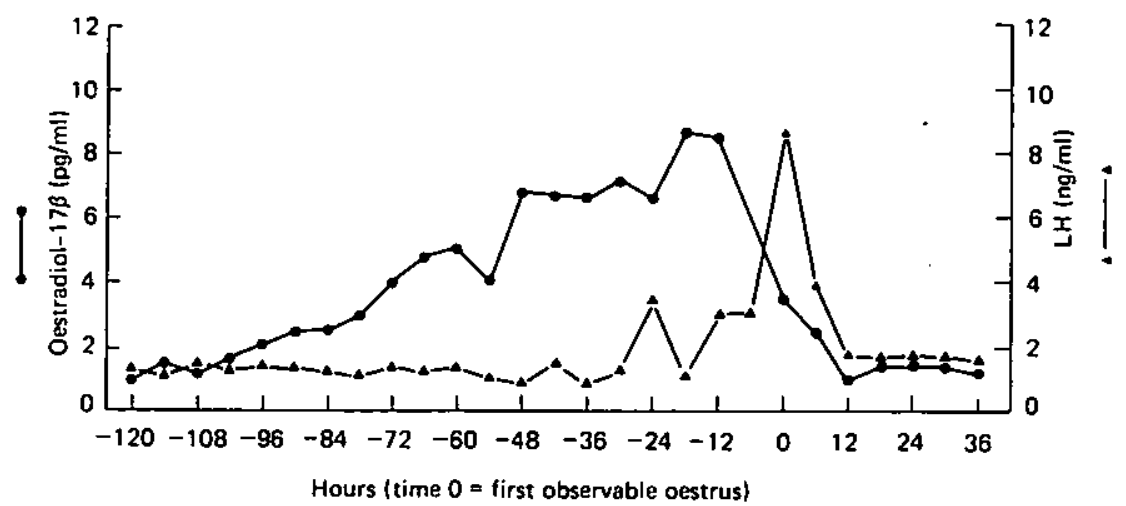

Figure 7.2 Mean plasma hormone concentrations in gilts reaching puberty after exposure to boars $(n=4)$. From Esbenshade et al. (1982)

In all the gilts reaching puberty in these studies the only changes in $\mathrm{LH}$ seen were those associated with the pre-ovulatory surge; that is, no changes in LH in response to surgery, relocation or boar exposure which could be considered causative of the initiation of follicle growth were detected. Such changes have been detected in the mouse (Bronson and Maruniak, 1976) and the ewe (Martin, Oldham and Lindsay, 1980). It is possible that the extremely low levels of circulating $\mathrm{LH}$ in the gilt compared with those in the mouse precluded detection of a subtle shift in the basal levels of this hormone. Alternatively, it may be that the change in LH is not in mean levels but in the frequency and/or amplitude of episodic pulses of LH as has been recently described in the ewe by Foster (1980). Such episodes are known to occur in the immature gilt (Elsaesser and Foxcroft, 1978) and the sampling regime used in our studies would make such changes impossible to detect.

We have also measured the hormonal profiles in two other gilts which responded to the introduction of boars by showing elevated levels of oestradiol but did not show oestrus or ovulation. Some follicle growth must have taken place in these gilts but it did not continue to ovulation and there was no positive feedback of oestrogen or $\mathrm{LH}$. The elevated oestrogen levels did not induce oestrus. The data suggest that the ability to respond to a stimulus by initiating follicle growth and the ability to respond to the resulting elevated oestradiol levels do not develop simultaneously. This finding may explain the phenomenon of vulval development without oestrus or ovulation which is often observed in young gilts, particularly after mixing or relocation.

It appears that boars stimulate puberty in gilts by affecting a rise in oestradiol levels. Whether the sequence of events leading to this rise, especially the change in basal $\mathrm{LH}$ secretion, is the same as has been described in other species such as the mouse still remains to be determined.

\section{Induction of puberty with exogenous gonadotrophins}

Casida (1935) first demonstrated that exogenous gonadotrophins can cause ovulation in immature gilts. Since then many workers have used pregnant 


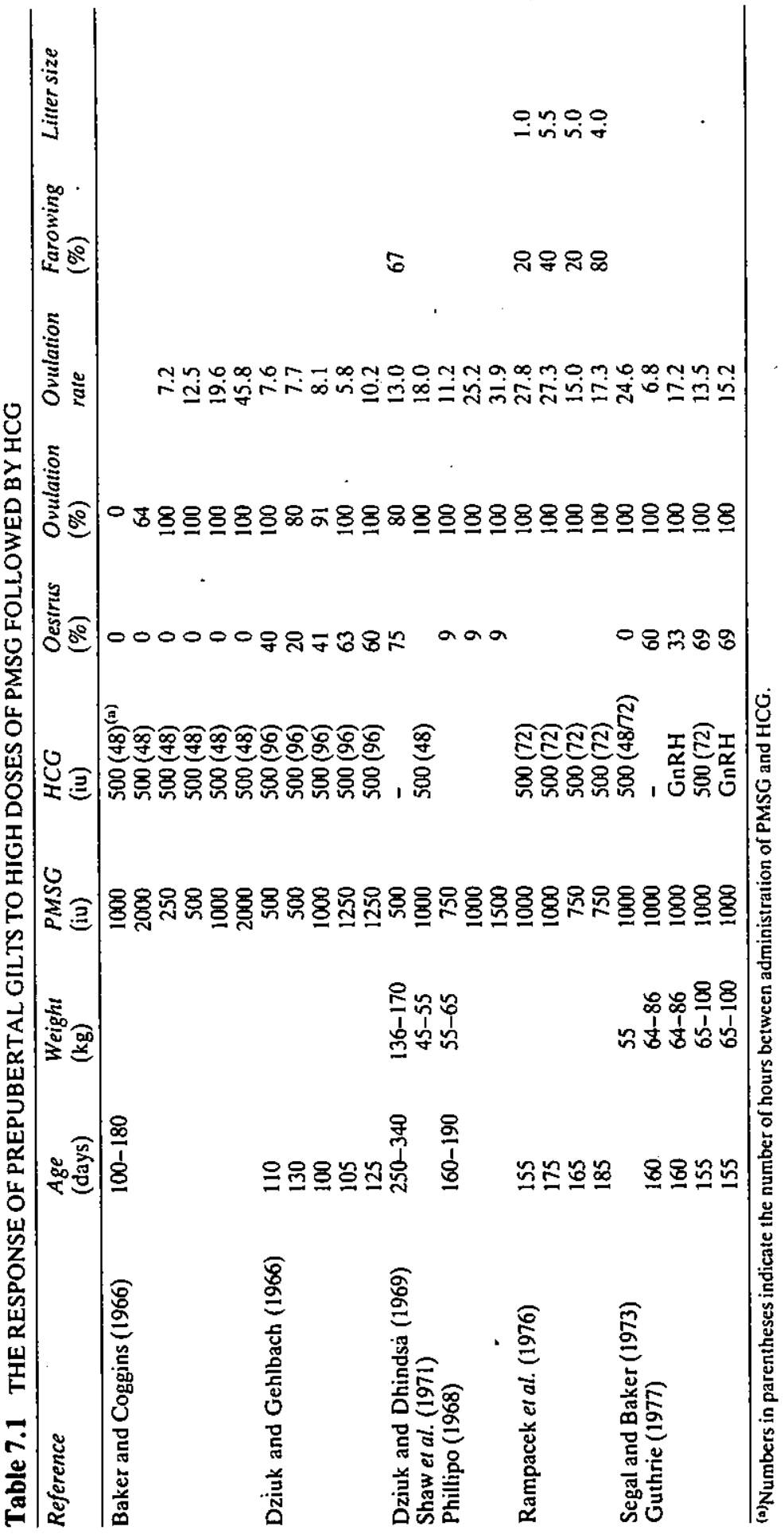


mare's serum gonadotrophin (PMSG) and human chorionic gonadotrophin (HCG) in attempts to stimulate precocious puberty in gilts.

Data from a number of experiments using PMSG followed by HCG to induce ovulation in prepubertal gilts are summarized in Table 7.1. Doses of 500-2000 iu PMSG followed by 500 iu HCG 48-96 hours later caused ovulation in up to $100 \%$ of gilts over a range of ages and weights. Some exceptions have been reported, including the failure of any gilts to ovulate after 1000 iu PMSG in the work of Baker and Coggins (1966). However in general ovulation rate is related to the dose of PMSG given. Both Baker and Coggins (1966) and Phillipo (1968) established positive linear relationships between dose of PMSG and ovulation rate and Rampacek et al. (1976) found higher ovulation rates after 1000 iu than after 750 iu PMSG.

In the range considered, age did not appear to affect markedly the response to PMSG. Gilts differing in age by 20 days had similar ovulation rates in the work of Rampacek et al. (1976). Dziuk and Gehlbach (1966) found similar ovulation rates in gilts treated with $500 \mathrm{iu}$ PMSG at 110 or 130 days of age. A difference with age was found in their work for gilts given 1250 iu but it should be noted that the younger gilts had a lower ovulation rate than any other group, including those of the same age given $500 \mathrm{iu}$, suggesting that their response was abnormal. The gilts treated by Dziuk and Dhindsa (1969) had ovulation rates comparable with much younger gilts given the same dose by Baker and Coggins (1966). Ovulation rate varies among experiments but this is probably due to factors other than chronological age, such as environment, hormone preparations and physiological differences among and within groups of gilts.

The ova produced in response to PMSG/HCG are capable of being fertilized (Dziuk and Polge, 1965) but reproductive performance after induction of puberty by this method has been poor. The data in Table 7.1 show that only a small percentage of gilts which ovulated exhibited oestrus. The highest incidence of oestrus was $75 \%$ (Dziuk and Dhindsa, 1969) but this was recorded in gilts which were much older than those treated by other workers, having failed to reach puberty naturally by 250 days of age or $136 \mathrm{~kg}$. In gilts around 160 days of age, the highest incidence of oestrus was $69 \%$ (Guthrie, 1977) but only $9 \%$ of those studied by Phillipo (1968) displayed oestrus. Segal and Baker (1973) showed that standing oestrus after PMSG treatment can be enhanced by injections of diethylstilboestrol given at the same time as HCG $(0$ versus $73 \%)$. However, this compound can influence sperm transport (Dziuk and Polge, 1965) which may adversely affect reproductive performance by causing asynchrony between ova and sperm at the time of fertilization.

Even when oestrus is displayed and breeding takes place, great variation in farrowing rate and litter size has been reported although acceptable farrowing rates have been obtained, e.g. 67\% (Dziuk and Dhindsa, 1969) and $80 \%$ (Holtz et al., 1977), but there are reports of farrowing rates as low as $20 \%$ (Rampacek et,al., 1976; Hühn, Heidler and Ressin, 1977) and a litter size as low as one live piglet has been recorded (Rampacek et al., 1976).

There have been reports that pregnancy in gilts induced to ovulate with PMSG may fail due to premature regression of the corpora lutea (Shaw, McDonald and Baker, 1971; Ellicott, Dziuk and Polge, 1973). In addition, 


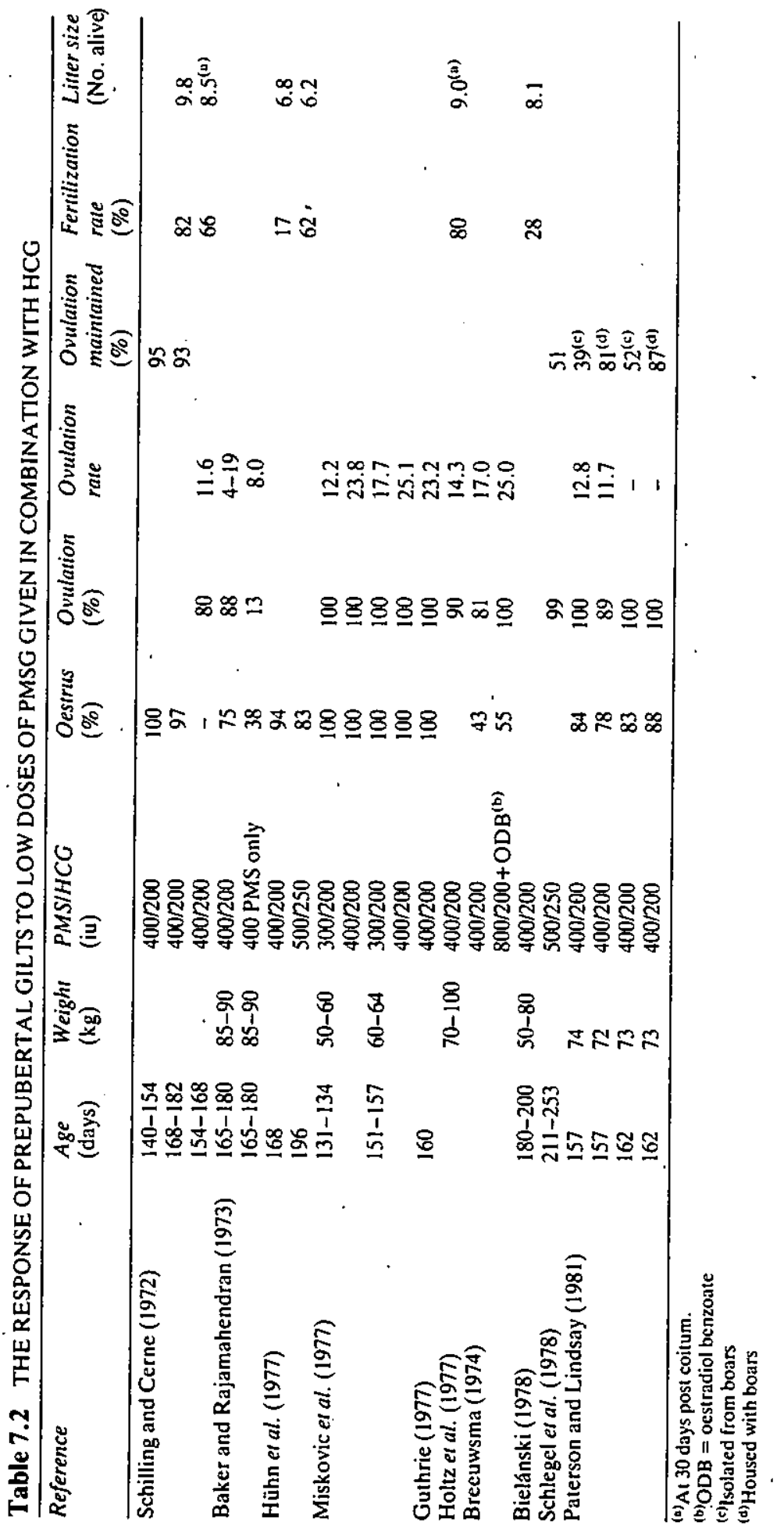


maintenance of cyclic activity to a second ovulation and oestrus in non-pregnant gilts may be poor (Dziuk and Gehlbach, 1966; Segal and Baker, 1973). However, this facet of the use of gonadotrophins to induce early puberty has not been systematically studied.

The use of PMSG to induce ovulation in prepubertal gilts, and mating at that ovulation, is not a satisfactory means of improving reproductive performance at this time. Mating at the second cycle after treatment offers an alternative but cyclic activity is not always maintained to a second oestrus and ovulation, which therefore precludes this practice.

Recently there has been interest in using PMSG and HCG in combination as a single injection. The combination most commonly used has been 400 iu PMSG and 200 iu HCG and these doses are considerably lower than those used in earlier work. Attention has centred on gilts around 150-180 days of age, which would be expected to be approaching the age of natural puberty. The results of some of the work in this area are summarized in Table 7.2.

In each experiment considered, $80 \%$ or more of treated gilts ovulated. Ovulation rates were generally lower than those found when high doses of PMSG followed by HCG were given but wide variation between experiments is still apparent. More gilts showed oestrus with several reports of up to $100 \%$ of the animals responding, although reports as low as $43 \%$ do exist (Breeuwsma, 1974). Data on the reproductive performance of these gilts is limited. Schilling and Cerne (1972) and Holtz et al. (1977) reported acceptable farrowing rates and litter sizes. However, other workers have found much lower fertilization rates and there is clearly a need for further research before the breeding of gilts after induction of ovulation with combinations of PMSG and HCG could be considered on a commercial basis.

Maintenance of cyclic activity in PMSG/HCG treated gilts has not been widely studied. Schilling and Cerne (1972) reported that over $90 \%$ of their gilts maintained cyclic activity but Schlegel, Wahner and Stenzel (1978) found a much lower incidence of second ovulation. In studies at the University of Western Australia (Paterson and Lindsay, 1981) it has also been found that maintenance of cyclic activity in gilts induced to ovulate with 400 iu PMSG and 200 iu HCG is poor. Of 41 gilts which ovulated in response to this treatment, $24(58 \%)$ ovulated a second time and only 19 of them $(46 \%)$ showed oestrus. Failure to maintain cyclic activity would severly limit the usefulness of this technique for the routine induction of puberty. We are able to show that this problem could be substantially reduced by using mature boars as an additional stimulatory factor. When gilts were housed in the presence of boars and exposed to them daily following the induction of ovulation, significantly more gilts displayed a second oestrus $\left(33 / 39\right.$ cf. $\left.19 / 41, \chi^{2}=11.2, P<0.001\right)$ and had a second ovulation ( $32 / 39$ cf. $\left.24 / 41, \chi^{2}=4.2, P<0.05\right)$ than when they were isolated from boars.

Based on these findings a management regime using induced ovulation, the presence of boars to facilitate the maintenance of cyclic activity and breeding of the gilts at their second oestrus may prove to be a viable commercial practice. Further study is warranted in this area, particularly with respect to maintenance of cyclic activity and reproductive performance. 
According to Gates and Bozarth (1978) the ovulatory process in response to PMSG in rodents is initiated by the FSH-like activity of the gonadotrophin which stimulates the maturation of the ovarian follicles. The growing follicles produce oestrogens, the circulating levels of which rise until, after a critical period, the hypothalamus is stimulated to release LH releasing hormone. This releasing hormone acts on the anterior pituitary gland to release $\mathrm{LH}$ and ovulation takes place several hours later. Similar hormonal data have recently been obtained in the pig. Esbenshade et al. (1982) gave prepubertal gilts $1000 \mathrm{iu}$ PMSG and collected blood samples twice daily for eight days. All the gilts showed oestrus five days after treatment and Figure 7.3 shows the mean hormone levels arranged
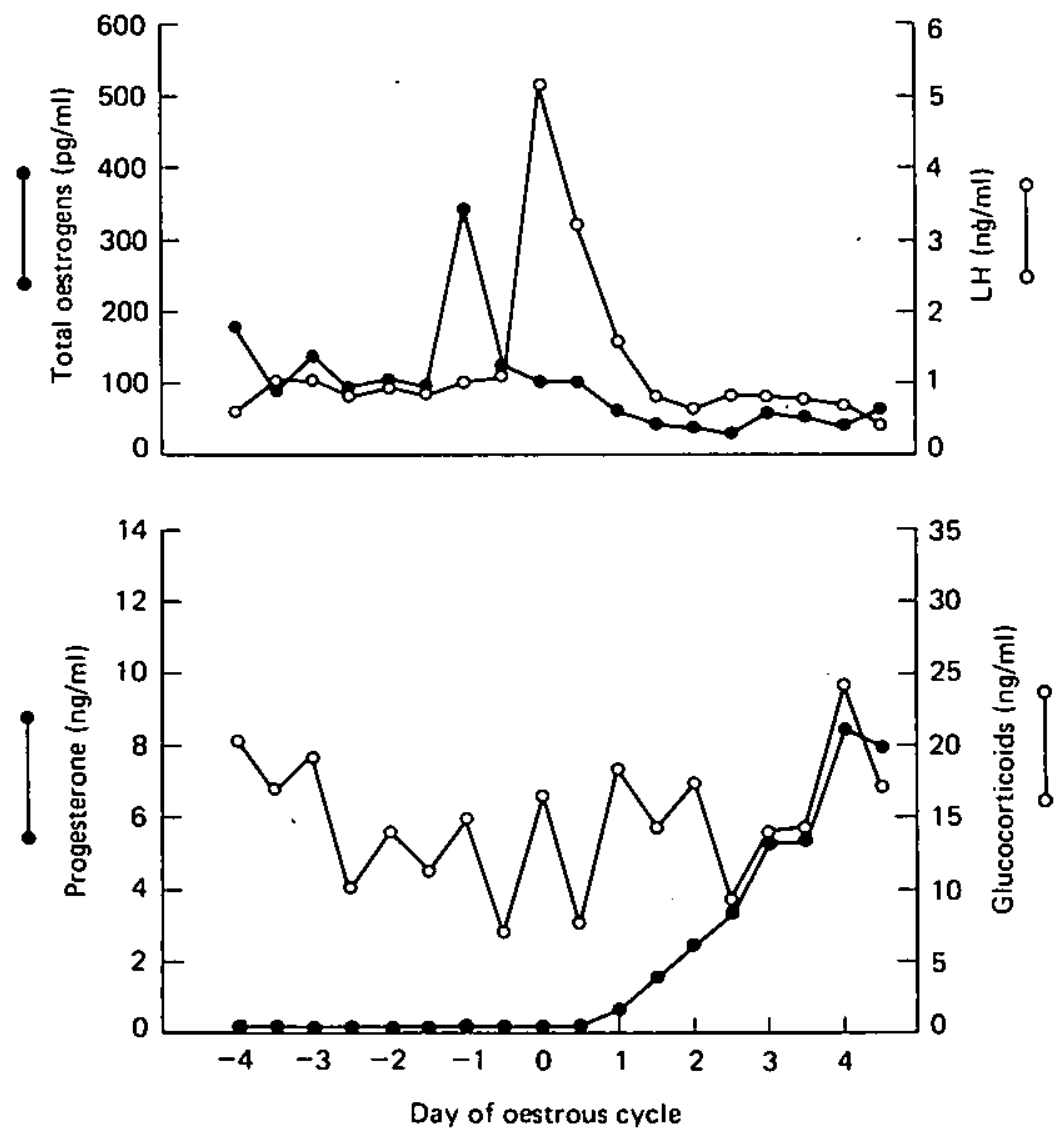

Figure 7.3 Mean plasma hormone concentrations in gilts induced to ovulate with $1000 \mathrm{iu}$ PMSG $(n=5)$. From Esbenshade et al. (1982)

with respect to the onset of oestrus (day 0 ). Plasma total oestrogens reached peak levels on day -1 and the pre-ovulatory surge of LH took place on the first day of oestrus. Paterson and Martin (1981) measured the levels of plasma oestradiol in gilts treated with $400 \mathrm{iu}$ PMSG and $200 \mathrm{iu}$ HCG in combination. The data in Table 7.3 show that oestradiol was 
Table 7.3 CHARACTERISTICS OF THE PLASMA OESTRADIOL-17B PATTERN OF GILTS INDUCED TO OVULATE WITH 400 iu PMSG AND 200 iu HCG

\begin{tabular}{llllll}
\hline $\begin{array}{l}\text { Gilt no. } \\
\text { ( } \begin{array}{l}\text { Boars }) \\
\text { Basal } \\
\text { (pg/ml) }\end{array}\end{array}$ & $\begin{array}{l}\text { Day of } \\
\text { Ist rise }\end{array}$ & $\begin{array}{l}\text { Day of } \\
\text { peak }\end{array}$ & $\begin{array}{l}\text { Peak } \\
\text { concentration } \\
(\mathrm{pg} / \mathrm{ml})\end{array}$ & $\begin{array}{l}\text { Day back } \\
\text { to basal }\end{array}$ \\
\hline $296+$ & 3.0 & 2 & 3 & 20.0 & 5 \\
$297+$ & U.D. $^{(\mathrm{b})}$ & 2 & 4 & 14.2 & 5 \\
$307+$ & 18.5 & 1 & 3 & 56.2 & 5 \\
$309+$ & 31.6 & 1 & 2 & 51.0 & 4 \\
$295-$ & 17.2 & 2 & 2 & 33.6 & 3 \\
$280+$ & 27.7 & 2 & 3 & 77.2 & 6 \\
$300+$ & 4.4 & 2 & 3 & 15.6 & 5 \\
$308+$ & 9.6 & 1 & 3 & 47.6 & 4 \\
$288-$ & 39.7 & 1 & 2 & 90.8 & 5 \\
$298-$ & 22.3 & 1 & 1 & 77.8 & 5 \\
$304-$ & U.D. & 1 & 3 & 27.0 & 5 \\
$306-$ & 13.6 & 3 & 6 & 203.1 & 10 \\
$287+$ & 21.0 & 1 & 2 & 34.4 & 4 \\
$290+$ & 26.7 & - & 3 & 54.6 & 4 \\
$299+$ & 4.5 & 1 & 2 & 41.4 & 5 \\
$305-$ & 8.6 & 1 & 1 & 21.0 & 5 \\
\hline
\end{tabular}

(a) Basal concentration is that of $-4,-2,0$.

(b) Below limit of detcction of the assay.

From Paterson (1979)

elevated two days after injection in $15 / 16$ gilts and peak levels were recorded on day 2 or 3 . The mean height of the peak was $52.9 \pm 12.51 \mathrm{pg} / \mathrm{ml}$ and the interval from the first rise until oestradiol concentration returned to basal levels was 3-4 days.

There are some similarities in the oestrogen response to PMSG and male stimuli. In both cases oestradiol rises quickly and remains elevated for some time before the pre-ovulatory surge of LH takes place. The hypothesis that a long period of elevated oestrogen titres is necessary for maturation of the hypothalamic positive feedback systems (Bronson, 1975; Bronson and Maruniak, 1976) fits the data for PMSG-induced ovulation as well as male-induced ovulation.

In an attempt to determine an endocrine basis for the failure of gonadotrophin-treated gilts to maintain cyclic activity, Paterson and Martin (1981) continued blood sampling through the luteal phase until after the time of the expected second oestrus. The hormonal patterns in the first follicular phase and during the luteal phase were similar to those reported in cyclic sows (Guthrie, Henricks and Handlin, 1972; Henricks, Guthrie and Handlin, 1972), and show that the ovaries of the prepubertal gilt around 160 days of age produce normal patterns and levels of oestradiol$17 \beta\left(\mathrm{E}_{2}\right)$ and progesterone in response to this combination of PMSG and HCG. Following the luteal phase three different types of cyclic activity were observed and each had a typical hormonal profile associated with it. A representative profile of each type is shown in Figure 7.4. Five gilts (type A) were able to produce a surge of $E_{2}$ which was associated with oestrus and ovulation while gilts (type B) were not able to do so, thus precluding any chance of oestrus or ovulation. Four other gilts (type $C$ ) produced a surge of $E_{2}$ and exhibited vulval development but ovulation did not take place. The $E_{2}$ produced may have failed to induce a pre-ovulatory surge of 

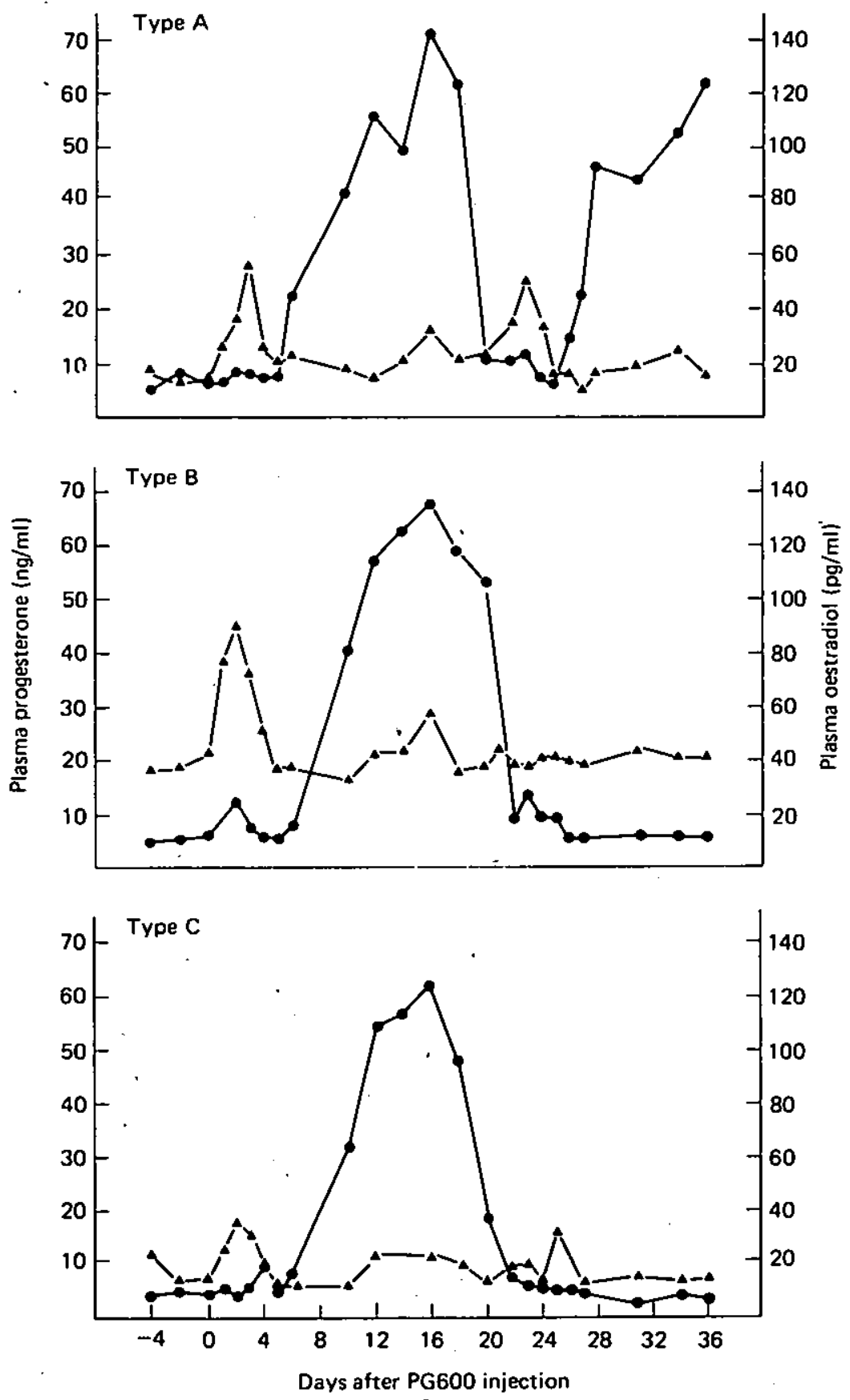

Figure 7.4 Plasma progesterone $(\bullet)$ and plasma oestradiol-17 $\beta(\Delta)$ in a gilt representing each type of cyclic activity observed after induction of ovulation with 400 iu PMSG and 200 iu HCG. From Paterson and Martin (1981). 
LH or too little LH may have been released to cause ovulation. Alternatively, the ovary may have become insensitive to the pre-ovualtory surge of LH. It may be that the basal LH secretory pattern in those animals which continue to cycle differ from those that do not, and this may be a possible explanation for the effect of the male on maintenance of cyclic activity. However, LH was not measured in this study and experimental confirmation of the role of $\mathrm{LH}$ in this process is still lacking.

\section{Induction of puberty with oestrogens}

As we have seen, the first changes in plasma hormones which have been observed at the onset of puberty in the gilt are changes in oestradiol. Bronson (1975) has shown that, in mice, the puberty-stimulating effect of the male can be replaced by exogenous oestrogen therapy. As long as plasma oestradiol remains elevated for two days, whether this is achieved by the presence of the male, the use of oestrogen injections or by a combination of the two, precocious puberty will result. This suggests that it should be possible to initiate cyclic activity in the gilt with oestradiol treatments. However, the few studies in which this has been attempted have produced equivocal results.

Dziuk (1965) reported that $15 / 20$ gilts showed oestrus after oral administration of $20 \mathrm{mg}$ ethinyl oestradiol/gilt/day for five days. Of the 10 gilts examined, eight had ovulated but the mean number of corpora lutea was only four/gilt and there were numerous unovulated follicles. This treatment regime failed to initiate normal recurring cycles. Baker and Downey (1975) reported similar results; of eight gilts injected with $40 \mathrm{mg}$ ethinyl oestradiol one showed oestrus and five ovulated. When $200 \mathrm{mg}$ ethinyl oestradiol was administered in a subcutaneous implant $7 / 8$ gilts showed oestrus and six ovulated. Treatment with the same doses of oestrone had no effect. In contrast, Hughes and Cole (1978) were successful in initiating cyclic activity in $6 / 10$ gilts around 140 days of age with injections of $0.4 \mathrm{mg}$ of oestradiol benzoate (ODB) on three successive days.

At the University of Missouri we have recently carried out a series of experiments examining the effect of ODB on oestrus and ovulation in prepubertal gilts around 180 days of age (Paterson and Day, 1980). In the first experiment $2 / 9$ gilts given $0.4 \mathrm{mg} O D B$ and $5 / 9$ given $0.8 \mathrm{mg}$ ODB showed oestrus, but $1 / 9$ and $0 / 9$ at each dose respectively had corpora lutea when examined on day 10.

Since Hughes and Cole (1978) achieved their success using repeated injections it was decided to compare the effect on oestrus and ovulation of a range of dose regimes of ODB. Forty eight gilts received a total of $1.2 \mathrm{mg}$ of ODB spread over either 1,2 or 3 days and given as either one or two injections per day, generating six treatment groups $(n=8)$. The results of this experiment are shown in Table 7.4. Most treated gilts showed vulval development but only six displayed oestrus. At laparoscopy 10-12 days post treatment 34 had quiescent ovaries, eight had ovulated and six had large unovulated follicles. Neither oestrus nor the distribution of these classes of ovarian activity were associated with ODB treatment. 
Table 7.4 OESTRUS AND OVULATION IN PREPUBERTAL GILTS TREATED WITH OESTRADIOL BENZOATE (ODB) IN THE ABSENCE OF BOARS

\begin{tabular}{lllllll}
\hline $\begin{array}{l}\text { Treatment } \\
\text { (mg ODB } \times \\
\text { injections) }\end{array}$ & $n$ & Oestrus & $\begin{array}{l}\text { Ovaries } \\
\text { immature }\end{array}$ & $\begin{array}{l}\text { Ovulating } \\
\text { normally }\end{array}$ & $\begin{array}{l}\text { Ovulation } \\
\text { with cysts }\end{array}$ & $\begin{array}{l}\text { Cysts/ } \\
\text { follicles }\end{array}$ \\
\cline { 2 - 7 } & & & 4 & 2 & 0 & 2 \\
\hline A : $0.4 \mathrm{mg} \times 3$ & 8 & 1 & 7 & 0 & 0 & 1 \\
B $: 0.6 \mathrm{mg} \times 2$ & 8 & 0 & 5 & 2 & 1 & 0 \\
C: $1.2 \mathrm{mg} \times 1$ & 8 & 2 & 4 & $!$ & 1 & 2 \\
D : $0.2 \mathrm{mg} \times 6$ & 8 & 1 & 8 & 0 & 0 & 0 \\
E: $0.3 \mathrm{mg} \times 4$ & 8 & 1 & 6 & 0 & 1 & 1 \\
F: $0.6 \mathrm{mg} \times 2$ & 8 & 1 & 8 & 0 & 0 & 0 \\
Control & 8 & 0 & & & & \\
\hline
\end{tabular}

Table 7.5 OESTRUS AND OVULATION IN PREPUBERTAL GILTS TREATED WITH OESTRADIOL BENZOATE (ODB) IN THE PRESENCE OF BOARS

\begin{tabular}{|c|c|c|c|c|c|}
\hline \multirow{2}{*}{$\begin{array}{l}\text { Treatment } \\
\text { (mg ODB } \times \text { injections) }\end{array}$} & \multicolumn{5}{|c|}{ Number of gills } \\
\hline & & & $\begin{array}{l}\text { Ovulating } \\
\text { normally }\end{array}$ & $\begin{array}{l}\text { Ovulation } \\
\text { with cysts }\end{array}$ & $\begin{array}{l}\text { Ovaries } \\
\text { immature }\end{array}$ \\
\hline $\begin{array}{l}0.4 \mathrm{mg} \times 1 \\
(n=8) \\
0.4 \mathrm{mg} \times 3 \\
(n=8) \\
1.2 \mathrm{mg} \times 1 \\
(n=8) \\
\text { Control } \\
(n=8)\end{array}$ & $\begin{array}{l}\text { Oestrus } \\
\text { No oestrus } \\
\text { Oestrus } \\
\text { No oestrus } \\
\text { Ocstrus } \\
\text { No oestrus } \\
\text { Oestrus } \\
\text { No oestrus }\end{array}$ & $\begin{array}{l}1 \\
7 \\
3 \\
5 \\
4 \\
4 \\
2 \\
6\end{array}$ & $\begin{array}{l}1 \\
0 \\
0 \\
2 \\
1 \\
1 \\
2 \\
1\end{array}$ & $\begin{array}{l}0 \\
0 \\
1 \\
0 \\
1 \\
1 \\
0 \\
0\end{array}$ & $\begin{array}{l}0 \\
7 \\
2 \\
3 \\
2 \\
2 \\
0 \\
5\end{array}$ \\
\hline
\end{tabular}

Both these experiments were conducted in the absence of boars to avoid the possibility of confounding their stimulatory effects with those of the ODB. The poor oestrous response obtained suggested that failure to detect oestrus may have been a factor in these experiments. To test this hypothesis groups of eight gilts were relocated, exposed to boars and given a range of ODB treatments. The data from this experiment (Table 7.5) clearly shows that the poor oestrous response observed in the first two experiments was not due to failure to detect oestrus. When similar ODB treatments were compared among the three experiments, the presence of boars $(\mathrm{B}+)$ had no significant effect on the proportion of gilts displaying oestrus $\left(B+8 / 24\right.$ cf. $\left.B-5 / 25, \chi^{2}=0.36\right)$ or the proportion ovulating $(B+$ $5 / 24$ cf. $B-6 / 25, \chi^{2}=0.002$ ).

Plasma hormone levels were not measured in these gilts but it may be suggested from data from ovariectomized gilts (Paterson et al., 1982) that treatments in which all the ODB was given on one day did not elevate plasma $E_{2}$ levels for long enough to produce an effect. Similarly, treatments using 0.2 or $0.3 \mathrm{mg}$ of $\mathrm{ODB}$ may not have caused a large enough rise in $E_{2}$ to stimulate oestrus and ovulation. However, the higher doses $(0.4$ or $0.6 \mathrm{mg}$ ) spread over 2 or 3 days should have been sufficient to keep plasma $E_{2}$ at concentrations above those seen in the normal prepubertal elevation (Esbenshade et al., 1982) for at least 80 hours. In addition Elsaesser and Foxcroft (1978) showed that similar doses of ODB to 160 days old gilts 
would induce an $\mathrm{LH}$ surge. The failure of these treatments to elicit oestrus and ovulation was surprising and the exact explanation for it is not apparent. Perhaps the natural rise in oestrogens prior to puberty is associated with changes in other hormones (for example LH, FSH or prolactin) which did not take place when oestrogens were artificially elevated with ODB but are necessary for oestrus and ovulation to take place.

In these experiments a wide range of ODB treatments failed to initiate cyclic activity. Overall $21 / 90$ gilts showed oestrus and $13 / 90$ ovulated. These results are in conflict with those of Hughes and Cole (1978) and no other published data are available for comparison. However, some recent work at the University of Nottingham initially reported by Foxcroft (1980) may provide an explanation. Their results suggest that the response of prepubertal gilts to ODB may be affected by season. In one experiment a total of 252 prepubertal gilts $(65-70 \mathrm{~kg}$ liveweight) were treated with $1.2 \mathrm{mg}$ ODB/gilt over the period May to December. The results in Figure 7.5 show that the percentage of animals showing follicular development

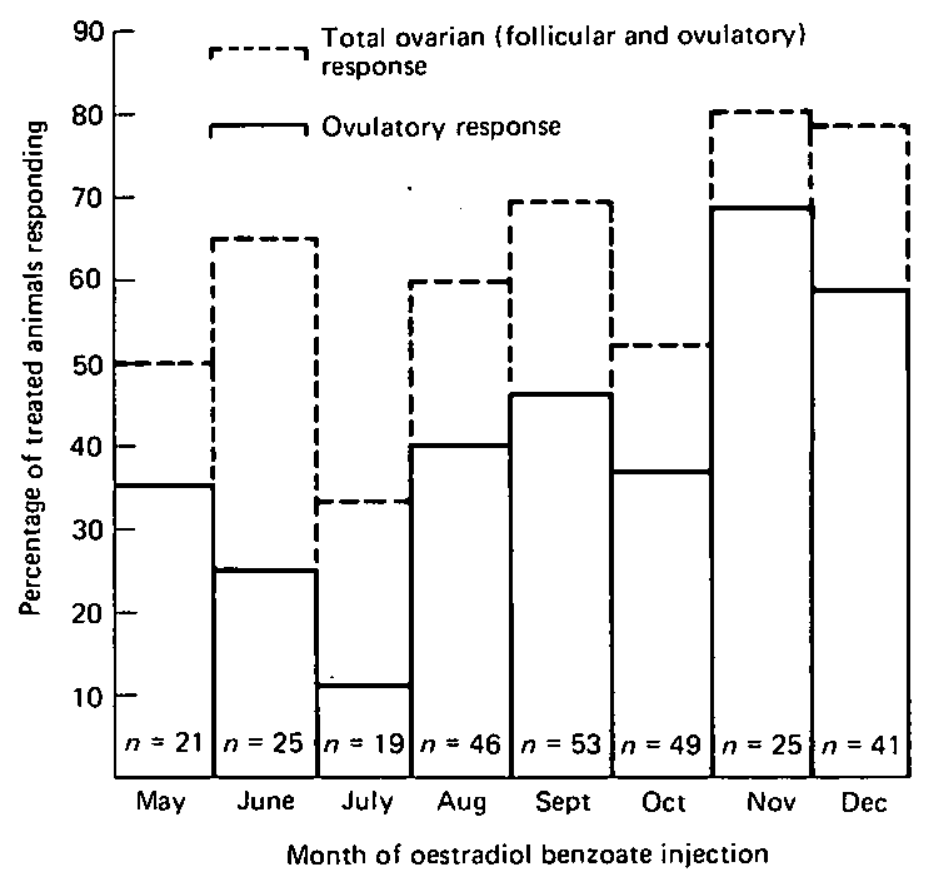

Figure 7.5 Variation with the month of treatment on the ovarian response of prepubertal gilts to $1.2 \mathrm{mg}$ oestradiol benzoate. From Stickney and Foxcroft (unpublished data)

and the percentage ovulating followed a marked seasonal trend. Much greater responses were obtained in the winter months, when up to $70 \%$ of treated gilts ovulated, compared with about $10 \%$ in July.

In a second experiment conducted between February and December gilts given $1.2 \mathrm{mg}$ ODB again exhibited a marked decline in ovulation response in the summer months (Figure 7.6). In contrast, gilts given 


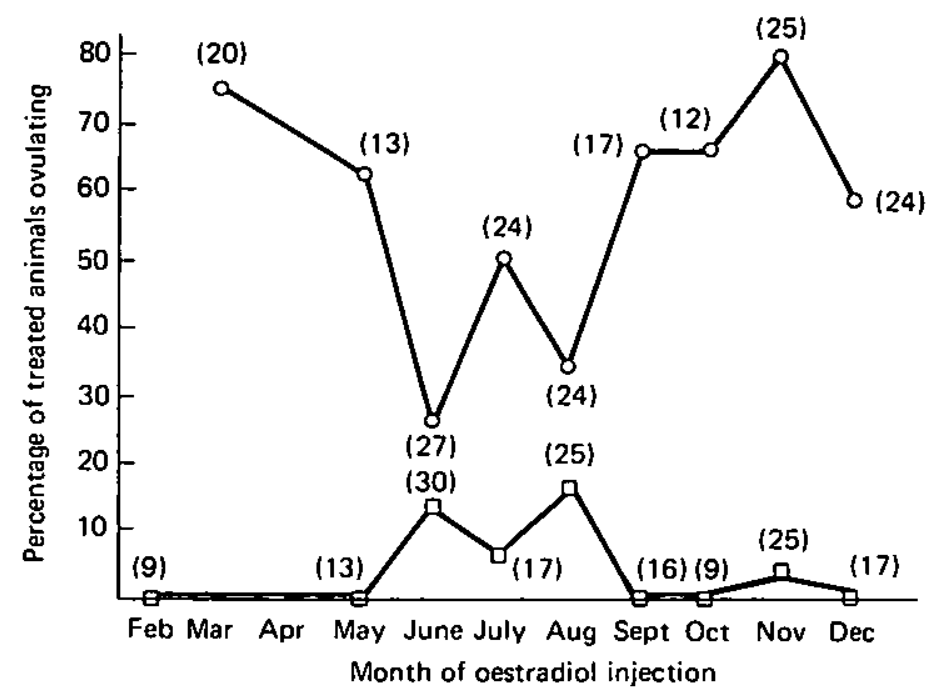

Figure 7.6 Variation with the month of treatment on the ovarian response of prepubertal gilts to $1.2(\mathrm{O}-\mathrm{O})$ or $0.12(\square-\square) \mathrm{mg}$ oestradiol benzoate. Figures in parentheses are number of gilts treated. Stickney and Foxcroft (unpublished data)

$0.12 \mathrm{mg}$ ODB demonstrated an ovulation response only in the summer months. Although the response to $0.12 \mathrm{mg}$ was much lower than that to $1.2 \mathrm{mg}$ ODB at the same time of year, it is consistent with the hypothesis that the seasonal effect may be mediated via variation in plasma oestrogen levels. Data from endocrine studies (Stickney and Foxcroft, unpublished data) indicate that plasma $E_{2}$ in response to the same dose of ODB is higher in summer than winter. Thus, the use of a high dose of ODB in winter may supply the correct steroid environment for inducing ovulation whereas such a dose in summer may inhibit ovulation. Conversely, a dose of $0.12 \mathrm{mg}$ ODB in winter is not sufficient to elicit a response, but in summer this dose does have some effect. From a practical point of view it seems likely that the optimum ODB dosage for maximum responses throughout the year is somewhere within the range tested and that the dose used should be varied according to the month of administration. Clearly, this area requires further investigation, but it does hold promise as a means of reliably inducing synchronized puberty in the gilt.

\section{Conclusions}

As the gilt approaches puberty the frequency of episodic LH secretion increases and this is believed to provide the trigger for final follicular maturation and ovulation. When puberty is induced by exposure to a boar the first endocrine change so far observed is an increase in the levels of circulating oestradiol. Whether this increase in oestrogens is mediated via an increase in episodic LH secretion has yet to be determined, but evidence from the sheep and the mouse, in which LH levels have been shown to change in animals exposed to males, suggests that this is likely. 
Treatment with exogenous hormones has not yet provided a useful method for the controlled induction of puberty in the gilt. The use of large doses of PMSG followed by HCG has many problems associated with it which precludes its adoption as a routine procedure. These include variable oestrous responses, poor reproductive performance, failure of the corpora lutea to persist in pregnant animals and failure to maintain cyclic activity in non-pregnant gilts. The use of low doses of PMSG and HCG in combination shows some promise as a method for the controlled induction of puberty, but further studies particularly on the maintenance of cyclic activity are required before this technique could be applied on a commercial basis.

Limited work with oestrogens has produced conflicting results and these compounds cannot be considered for the routine induction of puberty in practice at this time. However, the recent finding that the response to oestrogens follows a seasonal trend has increased our knowledge of this technique and promises to lead to a commercially viable system for controlling the onset of puberty. Finally, it also emphasizes the need to consider carefully the conditions under which induction experiments are carried out because many factors may interact to affect the response of gilts to such treatments. For this reason particular care in interpretation should be taken when making recommendations for the practical application of such techniques.

\section{References}

BAKER, R.D. and COGGINS, E.G. (1966). Induced ovulation and fertility in immature gilts. J. Anim. Sci. 25, 918 (Abstract)

BAKER, R.D. and DOWNEY, B.R. (1975). Induction of estrus, ovulation and fertility in prepubertal gilts. Annl Biol. anim. Biochim. Biophys. 15, 375-382

BAKER, R.D. and RAJAMAHENDRAN, R. (1973). Induction of estrus, ovulation and fertilization in prepubertal gilts by a single injection of PMSG, HCG and PMSG:HCG combination. Can. J. Anim. Sci. 53, 693-694

BIELANSKI, A. (1978). The possibilities of a reduction in the age at first farrowing. Anim. Breed. Abstr. 46, 581

BOOTH, W.D. (1975). Changes with age in the occurrence of $\mathrm{C}_{19}$ steroids in the testes and submaxillary gland of the boar. J. Reprod. Fert. 42, 459-472

BOOTH, W.D. (1977). Metabolism of androgens in vitro by the submaxillary salivary gland of the mature domestic boar. J. Endocr. 75, 145-154

BREEUWSMA, A.J. (1974). Induction of oestrus and ovulation in prepubertal and anoestrous pigs. 3rd Int. Congr. Int. Pig Vet. Soc., Lyon, pp. G14, 1-5

BRONSON, F.H. (1975). Male-induced precocial puberty in female mice: confirmation of the role of estrogen. Endocrinology 96, 511-514

BRONSON, F.H. and DESJARDINS, C. (1974). Circulating concentrations of FSH, LH, estradiol and progesterone associated with acute, maleinduced puberty in female mice. Endocrinology 94, 1658-1668

BRONSON, F.H. and MARSDEN, H.M. (1964). Male-induced synchrony of estrus in deermice. Gen. Comp. Endocr. 4, 634-637 
BRONSON, F.H. and MARUNIAK, J.A. 1975). Male-induced puberty in female mice: evidence for a synergistic action of social cues. Biol. Reprod. 13, 94-98

BRONSON, F.H. and MARUNIAK, J.A. (1976). Differential effects of male stimuli on follicle-stimulating hormone, luteinizing hormone, and prolactin secretion in pubertal female mice. Endocrinology 98, 1101-1108

BRONSON, F.H. and WHITTEN, W.K. (1968). Oestrus-accelerating pheromone of mice: assay, androgen-dependency and presence in bladder urine. $J$. Reprod. Fert. 15, 131-134

BROOKS, P.H. and COLE, D.J.A. (1969). The effect of boar presence on the age at puberty of gilts. Rep. Sch. Agric. Univ. Nott. (1968-69) pp. 74-77

BROOKS, P.H. and COLE, D.J.A. (1970). The effect of the presence of a boar on attainment of puberty in gilts. J. Reprod. Fert. 23, 435-440

CASIDA, L.E. (1935). Prepubertal development of the pig ovary and its relation to stimulation with gonadotrophic hormones. Anat. Rec. 61, 389-396

COOPER, K.J. and HAYNES, N.B. (1967). Modification of the oestrous cycle of the underfed rat associated with the presence of the male. J. Reprod. Fert. 14, 317-320

DAVIDSON, J.M. (1974). Hypothalamic-pituitary regulation of puberty: evidence from animal experimentation. In Control of the Onset of Puberty, (M.M. Grumbach, G.D. Grave and F.E. Mayer, Eds.), pp. 79-103. New York, John Wiley and Sons

DEBELUUK, L.. ARIMURA, A. and SCHALLY, A.V. (1972). Studies on the pituitary responsiveness to luteinizing hormone-releasing hormone (LH-RH) in intact male rats of different ages. Endocrinology 90 , 585-588

DOMINIC, C.J. (1965). The origin of the pheromones causing pregnancy block in mice. J. Reprod. Fert. 10, 469-472

DU MESNIL DU BUISSON, F. and SIGNORET, J.P. (1962). Influences de facteurs externes sur le déclenchement de la puberté chez la truie. Ann. Zootech. 11, 53-59

DUNCAN, D.L. and LODGE, G.A. (1960). Diet in relation to reproduction and viability of the young. Part III, Pigs. Commonwealth Bureau of Animal Nutrition Tech. Comm. No. 21. Rowett Research Institute, Bucksburn, Aberdeen.

DYRMUNDSSON, O.R. and LEES, J.L. (1972). Effect of rams on the onset of breeding activity in Clun Forest ewe lambs. J. agric. Sci., Camb. 79, 269-271

DZIUK, P.J. (1965). Response of sheep and swine to treatments for the control of ovulation. USDA Mis. Pub. 1005, 50-53

DZIUK, P.J. and DHINDSA, D.S. (1969). Induction of heat, ovulation and fertility in gilts with delayed puberty. J. Anim. Sci. 29, 39-41

DZIUK, P.J. and GEHLBACH, G.D. (1966). Induction of ovulation and fertilization in the immature gilt. J. Anim. Sci. 25, 410-413

DZIUK, P.J. and POLGE, C. (1965). Fertility in gilts following induced ovulation. Vet. Rec. 77, 236-238

ELLICOTT, A.R., DZIUK, P.J. and POLGE, C. (1973). Maintenance of pregnancy in prepubertal gilts. J. Anim. Sci. 37, 971-973

ELSAESSER, F. and FOXCROFT, G.R. (1978). Maturational changes in the 
characteristics of oestrogen-induced surges of luteinizing hormone in immature domestic gilts. J. Endocr. 78, 455-456

ESBENSHADE. K.L., PATERSON, A.M., CANTLEY, T.C. and DAY, B.N. (1982). Changes in plasma hormone concentrations associated with the onset of puberty in the gilt. J. Anim. Sci. 54, 320-324

FOSTER, D.L. (1980). Comparative development of mammalian females: proposed analogies among patterns of $\mathrm{LH}$ secretion in various species. In Proceedings of the Serono Symposia 32, (C. La Cauza and A.W. Root, Eds.), pp. 193-209. London, Academic Press.

FOSTER, D.L. COOK, B. and NALBANDOV, A.V. (1972). Regulation of luteinizing hormone (LH) in the fetal and neonatal lamb: effect of castration during the early postnatal period on levels of LH in sera and pituitaries of neonatal lambs. Biol. Reprod. 6, 253-257

FOXCROFT, G.R. (1978). The development of pituitary gland function. In The Control of Ovulation (D.B. Crighton, G.R. Foxcroft, N.B. Haynes and G.E. Lamming, Eds.), pp. 117-138. London, Butterworths

FOXCROFT, G.R. (1980). Growth and breeding performance in animals and birds. In Growth in Animals (T.L.J. Lawrence, Ed.), pp. 229-247. London, Butterworths

GATES, A.H. and BOZARTH, J.L. (1978). Ovulation in the PMSG-treated immature mouse: effect of dose, age, weight, puberty, season and strain (BALBc 129 and C129F, Hybrid). Biol. Reprod. 18, 497-505

GORSKI, R.A. (1974). Extrahypothalamic influences on gonadotrophin regulation. In Control of the Onset of Puberty (M.M. Grumbach, G.D. Grave and F.E. Mayer, Eds.), pp. 182-207. New York, John Wiley and Sons

GOWER, D.B. (1972). 16-unsaturated $C_{19}$ steroids. A review of their chemistry, biochemistry and possible physiological role. J. Steroid Biochem. 3, 45-103

GRUMBACH, M.M., ROTH, J.C., KAPLAN, S.L. and KELCH, R.P. (1974). Hypothalamic-pituitary regulation of puberty in man: evidence and concepts derived from clinical research. In Control of the Onset of Puberty (M.M. Grumbach, G.D. Grave and F.E. Mayer, Eds.), pp. 115-181. New York, John Wiley and Sons

GUTHRIE, H.D. (1977). Induction of ovulation and fertility in prepubertal gilts. J. Anim. Sci. 45, 1360-1367

GUTHRIE, H.D., HENRICKS, D.M. and HANDLIN, D.L. (1972). Plasma estrogen, progesterone and luteinizing hormone prior to estrus and during early pregnancy in pigs. Endocrinology 91, 675-679

HENRICKS, D.M., GUTHRIE, H.D. and HANDLIN, D.L. (1972). Plasma estrogen, progesterone and luteinizing hormone levels during the estrous cycle in pigs. Biol. Reprod. 6, 210-218

HOLTZ, W., POlANCO, A., von KAUfMANN, F. and HERRMANN, H.H. (1977). Induction of precocious ovulation in gilts. Proceedings: Society for the Study of Fertility, Nottingham, Abstract 10

HUGHES, P.E. and COLE, D.J.A. (1978). Reproduction in the gilt. 3. The effect of exogenous oestrogen on the attainment of puberty and subsequent reproductive performance. Anim. Prod. 27, 11-20

HÜHN, U., HEIDLER, W. and RESSIN, E. (1977). Induction of sexual maturity in prepubertal gilts by gonadotrophins. 2 . Reproductive performance of 
puberty-induced gilts following oestrous synchronization and artificial insemination. Anim. Breed. Abstr. 45, 242

KINSEY, R.E., CARLSON, R., PROUD, C. and ZIMMERMAN, D.R. (1976). Influence of boar stimuli on age at puberty in gilts. J. Anim. Sci. 42, 1362 (Abstract)

KIRKWOOD, R.N. and HUGHES, P.E. (1980). A note on the influence of 'boar effect' component stimuli on puberty attainment in the gilt. Anim. Prod. 31, 209-211

KIRKWOOD, R.N., FORBES, J.M. and HUGHES, P.E. (1981). Influence of boar contact on attainment of puberty in gilts after the removal of the olfactory bulbs. J. Reprod. Fert. 61, 193-196

LEVASSEUR, M.C. (1977). Thoughts on puberty. Initiation of gonadotrophic function. Annls Biol. anim. Biochim. Biophys. 17, 345-361

MARTIN, G.B., OLDHAM, C.M. and LINDSAY, D.R. (1980). Increased plasma $\mathrm{LH}$ levels in seasonally anovular Merino ewes following the introduction of rams. Anim. Reprod. Sci. 3, 125-132

MISKOVIC, M., SIMIC, M., JOJKIC, M. and STANCIC, B. (1977). Ovulation induction in prepubertal gilts using PMS and HCG. Anim. Breed. Abstr. 45, 118

PARKES, A.S. and BRUCE, H.M. (1962). Pregnancy-block in female mice placed in boxes soiled by males. J. Reprod. Fert. 4, 303-308

PATERSON, A.M. (1979). The reproductive performance of sows and gilts under intensive conditions. PhD Thesis. University of Western Australia

PATERSON, A.M. and DAY, B.N. (1980). The effect of estradiol benzoate on estrus and ovulation in prepubertal gilts. J. Anim. Sci. 51, (Suppl. 1) 88

PATERSON, A.M. and LINDSAY, D.R. (1981). Induction of puberty in gilts. 2. The effect of boars on maintenance of cyclic activity in gilts induced to ovulate with PMSG and HCG. Anim. Prod. 32, 51-54

PATERSON, A.M. and MARTIN, G.B. (1981). Induction of puberty in gilts. 3. Ovulation, plasma oestradiol and progesterone in gilts injected with PMSG and HCG. Anim. Prod. 32, 55-59

PATERSON, A.M., CANTLEY, T.C., ESBENSHADE, K.L. and DAY, B.N. (1982). Glucocorticoids and estrus in swine. II. Plasma levels of estradiol-17 $\beta$ glucocorticoids and LH in ovariectomized gilts given estradiol benzoate and triamcinolone acetonide. J. Anim. Sci. (submitted for publication)

PHILlIPO, M. (1968). Superovulation in the pig. Adv. Reprod. Physiol. 3, $147-166$

RAMIREZ, V.D. and MCCANN, S.M. (1963). Comparison of the regulation of luteinizing hormone (LH) secretion in immature and adult rats. Endocrinology 72, 452-464

RAMPACEK, G.B., SCHWARTZ, F.L., FELLOWS, R.E., ROBISON, O.W. and ULBERG, L.C. (1976). Initiation of reproductive function and subsequent activity of the corpora lutea in prepubertal gilts. J. Anim. Sci. 46, $881-887$

REDMER, D.A. and DAY, B.N. (1981). Ovarian activity and hormonal patterns in gilts fed allyl trenbolone. J. Anim. Sci. 53, 1088-1094

REED, H.C.B., MELROSE, D.R. and PATTERSON, R.L.S. (1974). Androgen steroids as an aid to the detection of oestrus in pig artificial insemination. Br. vet. J. 130, 61-67

RYAN, K.D. and FOSTER, D.L. (1980). Neuroendocrine mechanisms involved 
in the onset of puberty in the female: concepts derived from the lamb. Fed. Proc. 9, 2372-2377

SCHILLING, E: and CERNE, F. (1972). Induction and synchronization of oestrus in prepubertal gilts and anoestrous sows by a PMS/HCG compound. Vet. Rec. 91, 471-474

SCHLEGEL, W., WAHNER, M. and STENZEL, S. (1978). Studies into the further course of the cycle following biotechnical induction of puberty in gilts. Anim. Breed. Abstr. 46, 585

SEGAL, D.H. and BAKER, R.D. (1973). Maintenance of corpora lutea in prepubertal gilts. J. Anim. Sci. 37, 762-767

SHAW, G.A., McDONALD, B.E. and BAKER, R.D. (1971). Fetal mortality in the prepubertal gilt. Can. J. Anim. Sci. 51, 233-236

SHEARER, I.J., PURVIS, K., JENKINS, G. and HAYNES, N.B. (1972). Peripheral plasma progesterone and oestradiol- $17 \beta$ levels before and after puberty in gilts. J. Reprod. Fert. 30, 347-360

VANDENBERGH, J.G. (1969). Male odor accelerates female sexual maturation in mice. Endocrinology 84, 658-660

VANDENBERGH, J.G. (1975). Pheromonal stimulation of puberty in female mice. J. Endocr. 64, 38p (Abstract)

WHITTEN, W.K. (1956a). Modification of the oestrous cycle of the mouse by external stimuli associated with the male. J. Endocr. 13, 399-404

WHITTEN, W.K. (1956b). The effect of removal of the olfactory bulbs on the gonads of mice. J. Endocr. 14, 160-163

WILSON, E.O. and BOSSERT, W.H. (1963). Chemical communication among animals. Recent Progr. Horm. Res. 19, 673-710 